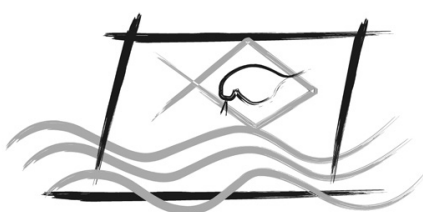

ECOTOX - BRASIL

\title{
Toxicity of Diuron, Diquat and Terbutryn to Cyanobacterial Mats
}

\author{
Yasser EL-Nahhal; Salah M.F. Kerkez \& Zeyad Abu Heen \\ Department of Environmental and Earth Sciences, Faculty of Science, The Islamic University-Gaza
}

(Received July 10, 2015; Accept September 29, 2015)

\begin{abstract}
This study investigated acute toxicity of Diuron, Diquat and Terbutryn to cyanobacterial mats collected from Wadi Gaza, Palestine. Toxicity was measured by the reduction of population growth of cyanobacterial mats exposed to various herbicide concentrations in the range of 0-15.44 $\mu$ mole $\mathrm{L}^{-1}$. Optical density of cyanobacterial suspension was recorded using a spectrophotometer at $680 \mathrm{~nm}$ from time zero up to 8 days and taken as an indicator of growth. $\mathrm{EC}_{50}$ and $\mathrm{ET}_{50}$ values were estimated using linear regression equations. Results showed that cyanobacterial mats adapted and grew fast under laboratory conditions. The toxicity of Diuron, Terbutryn and Diquat reached 89.35, 76.02 and 71.24\%, respectively. Toxicity of binary mixtures (Diuron and Diquat) decreased from $77.35 \%$ to $65.33 \%$ due to the reduction of Diuron concentration in the mixture. $\mathrm{EC}_{50}$ values for Diuron, Terbutryn and Diquat were 0.009, 0.031 and $0.381 \mu$ mole $\mathrm{L}^{-1}$ whereas $\mathrm{ET}_{50}$ values were $32.32,35.89$ and $23.45 \mathrm{~h}$, respectively. $\mathrm{EC}_{50}$ values of binary mixtures (B1-B3) were $0.004,0.01$ and 0.012 toxicity units. Tertiary mixtures (T1-T7) had a wide range of $\mathrm{EC}_{50}(0.043-2.9 \mathrm{E}-07)$ TUs. The mixture toxicity index (MTI) had positive and negative value in mixtures, indicating synergetic and antagonistic effects. Application of the above-mentioned herbicides may severely damage the ecosystem. Our results are the first of its kind in the region and may be considered as a guideline for future studies.
\end{abstract}

Key words: Toxicity, Herbicides, Cyanobacterial mats, $\mathrm{EC}_{50}, \mathrm{ET}_{50}$, Toxicity Units.

\section{INTRODUCTION}

Application of pesticides has resulted in the contamination of food samples and agricultural commodities in many countries (El-Nahhal, 2004). Considerable health hazards have been associated with pesticides application. For example, cancer cases have been reported in Gaza farm workers (Safi, 2002, Safi et al., 2005, El-Nahhal and Radwan 2013). Effects of pesticides in non-target organisms have also been reported elsewhere (Miller, 2009).

However, pesticide residues are present as mixtures in the environment. They may undergo additive synergistic or antagonistic effects that can alter the balance of ecosystems (Wendt-Rasch, et al., 2004).

Cyanobacterial mats are not target organisms. They are ecologically important due to their essential roles in nutrient cycling, oxygen production and ability to fix atmospheric nitrogen (Ma et al., 2010, Okman \& Uger, 2011).
A number of studies highlighted the ability of cyanobacteria to degrade organic pollutants, including pesticides (El-Nahhal et al., 2013, Safi et al., 2014).

Pesticides application in Gaza increased rapidly from 250 tons of formulated pesticides to more than 425 tons (El-Nahhal \& Radwan 2013). The use of pesticides in Gaza has been associated with toxicity to fish and mosquitoes (El-Nahhal et al., 2015), phytotoxicity to non-target plants (El-Nahhal \& Hamduna, 2015), unicellular algae and direct toxic effects on populations of phytoplankton (Ma et al., 2003).

Several studies investigated single toxicity to cyanobacteria (Chen et al. 2007, Aslim \& Ozturke 2009, Inderjit- Kaushik 2010, Ma et al. 2010).

However, few studies investigated the toxicity of chemical mixtures (El-Nahhal et al., 2015; El-Nahhal \& Ashanti 2015). Moreover, previous studies investigated the effects on pure cyanobacterial cultured in the laboratory but did not pay attention to tertiary mixtures.

*Corresponding author: Yasser El-Nahhal; e-mail: y_el_nahhal@hotmail.com 
The present study was initiated to investigate the toxicity of single, binary and tertiary mixture on wild type cyanobacterial mats collected from Wadi Gaza using a bioassay technique and to test the possibility of using chemoassays to evaluate toxicity and to investigate the influence of exposure time.

\section{MATERIALS AND METHODS}

Diuron, Diquat, Terbutryn and thiazolyl Blue Tetrazolium Bromide (Fig. 1) were purchased Sigma Aldrich, Germany selected physico-chemical properties are shown in Table 1. Cyanobacterial mats samples were collected from Wadi Gaza.

\section{Sampling of cyanobacterial mats cells}

All cyanobacterial mats samples were collected from the western part of Wadi Gaza near the Mediterranean Sea beach by using an algal net during May-August 2012. The mats were submerged in a plastic bottle full of green aqueous media from the surroundings of the mats (El-Nahhal et al., 2013). The temperature, $\mathrm{pH}$ and $\mathrm{EC}$ values were recorded during the experiments.

\section{Preparation of growth media}

Water samples were collected from the same site as the cyanobacteria, cleaned, and filtered through membrane filters

Table 1. Some physico-chemical properties of the tested herbicides according Tomlin (2000).

\begin{tabular}{lccccc}
\hline Compound & $\begin{array}{c}\text { MW (g } \\
\left.\mathrm{mole}^{-1}\right)\end{array}$ & $\begin{array}{c}\text { H const. } \\
\left(\mathrm{atm} \mathrm{m}^{3}\right. \\
\left.\mathrm{mole}^{-1}\right)\end{array}$ & $\begin{array}{c}\text { Log } \\
\mathrm{K}_{\mathrm{OW}}\end{array}$ & $\begin{array}{c}\text { Chemical } \\
\text { class }\end{array}$ & $\begin{array}{c}\text { Influenced } \\
\text { Mechanism }\end{array}$ \\
\hline Duiron & 233.1 & $7.04 \times 10^{-6}$ & 2.85 & Urea & PH S II. \\
Diquat & 344.1 & $5 \times 10^{-9}$ & -4.6 & Bipyridylium & $\begin{array}{c}\text { Damages cell } \\
\text { membranes }\end{array}$ \\
Terbutryn & 241.4 & $1.5 \times 10^{-3}$ & 3.65 & $1,3,5$ triazine & PH S II \\
\hline
\end{tabular}

Where MW, H-const., $\operatorname{LogK}_{\text {ow }}$, and PH SII are molecular weight, Henry constant, Log Octanol/water partitioning coefficient and photo system II, respectively.
(MF) (47-mm diameter, $0.45 \mu \mathrm{m})$. Then they were sterilized at $120^{\circ} \mathrm{C}$ for $25 \mathrm{~min}$ using an autoclave system.

\section{Preparation of cyanobacterial mats stock suspension}

The collected cyanobacterial mats were incubated in the laboratory at room temperature $\left(20-25{ }^{\circ} \mathrm{C}\right)$ and shaken carefully in aqueous media of and left for $30 \mathrm{~min}$. The mats were diluted with a growth media prepared to have an optical density of stock suspension of 0.14 . About $100 \mathrm{~mL}$ of the suspension was isolated and tested under a light microscope and considered as stock suspension of cyanobacterial mats. The salinity and $\mathrm{pH}$ of the stock solution were measured to adapt with the properties of growth media (Sauvant et al., 1999). A stock suspension volume of the mats was diluted with another volume of growth media to obtain a low concentration of mats with salinity and $\mathrm{pH}$, similar to that in their natural environment. The diluted suspension was gently shaken to insure normal distribution of cells by using magnetic stirrerKMC-130 SH for $10 \mathrm{~min}$.

\section{Determination of growth phases of cyanobacterial mats}

The mats were grown under lab conditions in order to monitor the growth phases and life cycle. Population growth of the cyanobacteria was measured by monitoring the optical density (OD) of growth solution using a spectrophotometer at a wavelength of $680 \mathrm{~nm}$ (Ma et al., 2003). Ten $\mathrm{mL}$ of the mats suspension was transferred to a $50 \mathrm{~mL}$ Erlenmeyer flask under controlled temperature $\left(25 \pm 1{ }^{\circ} \mathrm{C}\right)$. Light/dark cycles were provided by a 60 watt tungsten lamp 12-light:12-dark cycle using a special timer (Chen et al,. 2007). The experiment was performed in five replicates and the OD of the incubated mats suspension was recorded at 0, 24, 48, 72, 96, 120, 144, 168 and $192 \mathrm{~h}$. The population dynamics of the cyanobacterial mats were evaluated by plotting OD versus time (El-Nahhal \& Ashanti 2015).

\section{Toxicity of herbicides}

Toxicity of the tested herbicides on cyanobacterial mats were estimated as growth inhibition (GI) of the population. In these tests, a technical amount of Diuron, Diquat or Terbutryn in the range of $0-154 \mu$ mole $\mathrm{L}^{-1}$ was dissolved in
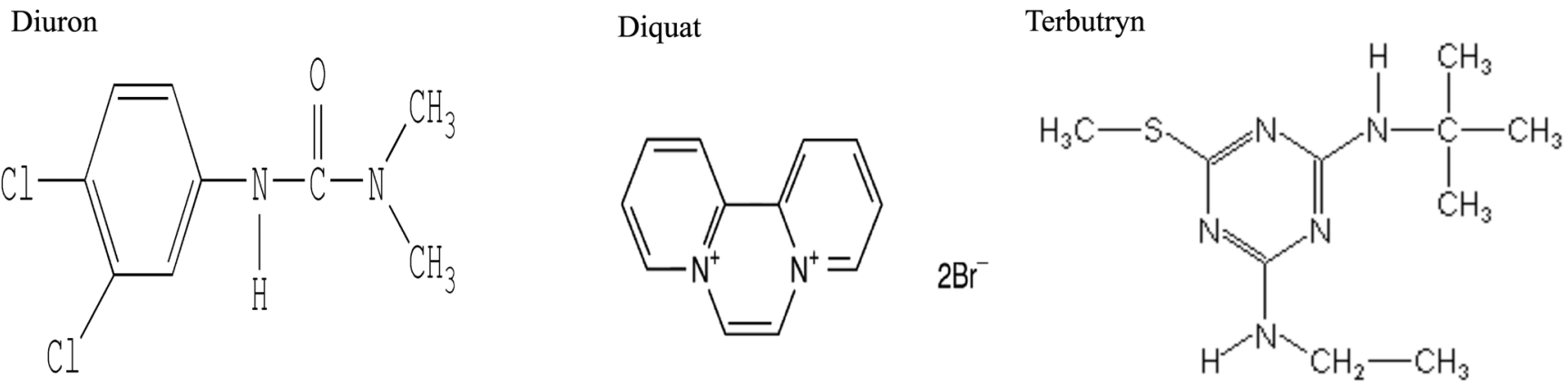

Figure 1. Chemical structure of the tested compounds. 
distilled water (chlorine free) and used as a stock solution. In this procedure, stock suspension of cyanobacterial mats and gradient concentrations of the herbicides (five dilutions from the stock) were prepared. Five $\mathrm{mL}$ of mats solution were added to six Erlenmeyer flasks, then $2 \mathrm{~mL}$ of each dilution of the herbicide was added to each flask and gently shaken to insure normal distribution of cells (Bonnet et al., 2007). Growth inhibition of the cyanobacterial mats were determined using Eq (1) (El-Nahhal \& Ashanti 2015).

$$
\% \mathrm{GI}=100 * \frac{(O D c-O D t)}{O D c}
$$

where $\mathrm{OD}_{\mathrm{c}}$ and $\mathrm{OD}_{\mathrm{t}}$ are the optical densities of the control and the treated samples, respectively. The toxicity ( $\%$ GI) of variant concentrations of herbicides was evaluated by plotting $\%$ growth inhibition versus time.

The dynamics of cyanobacterial mats cells growth (relative growth) in the control samples were evaluated by plotting time versus the $\mathrm{OD}_{\max } / \mathrm{OD}_{0}$ ratios, where $\mathrm{OD}_{\max }$ and $\mathrm{OD}_{0}$ are the optical densities at maximum growth and growth at time zero, respectively. Using an Excel program, the coefficient of correlation $\left(\mathrm{r}^{2}\right)$ and regression equations were recorded. From the regression correlation equation of $\%\left(\mathrm{OD}_{\mathrm{c}}-\mathrm{OD}_{\mathrm{t}} / \mathrm{OD}_{\mathrm{c}}\right)$ versus $\log$ herbicide concentrations, the $\mathrm{EC}_{50}$ was estimated, where $\mathrm{EC}_{50}$ is the effective concentration that caused $50 \%$ inhibition of the tested population (Ma et al., 2003). Percent growth inhibition results were regressed versus log time to estimate the $\mathrm{ET}_{50}$, where $\mathrm{ET}_{50}$ is the effective time leading to a $50 \%$ reduction in a chosen toxicity endpoint.

\section{Toxicity of binary and tertiary mixtures}

Preliminary stock solutions of binary mixtures (mixtures B1-3) of the herbicides (Diquat and Diuron) were selected and mixed together because they belong to different chemical groups and each has a different mode of action (Tomlin 200). Binary mixtures had the following ratios 7:3, 1:1 and 3:7 $(\mathrm{v} / \mathrm{v})$ and were prepared by combining aliquots diuron and Diquat, respectively.

Mixture B1 was $70 \%$ diuron and 30\% Diquat, mixture B2 was $50 \%$ diuron and $50 \%$ Diquat, while mixture $\mathrm{B} 3$ was $30 \%$ diuron and $70 \%$ diuat.

Tertiary mixtures (mixtures T1-6) included Diquat, Diuron, $\&$ Terbutryn of different combinations. The mixture ratios including T1 (0.333:0.333:0.0333), T2 (0.50: 0.25:0.25), T3 (0.25:0.50:0.25), T4 (0.25: 0.25:0.50), T5 (0.25: 0.15:0.70), and T6 $(0.70: 0.15: 0.15)(\mathrm{v} / \mathrm{v})$ were prepared by combining aliquots Diquat, Diuron, and Terbutryn, respectively. More details are shown in Table 2. Growth inhibition of cyanobacterial mats were determined as described above.

\section{Calculation of toxic units $\left(\mathrm{TU}_{\mathrm{S}}\right)$ in mixtures}

According to Sprogue \& Ramsay (1965), toxic units were calculated as: Toxic units = actual concentration in solution / lethal threshold concentration
Table 2. Composition of binary and tertiary solutions.

\begin{tabular}{|c|c|c|c|c|}
\hline \multirow{3}{*}{ Solution } & \multirow{3}{*}{$\begin{array}{c}\text { Diuron : Diquat: Terbutryn } \\
\qquad(\mathrm{v} / \mathrm{v})\end{array}$} & \multicolumn{3}{|c|}{$\begin{array}{l}\text { Concentration of } \\
\text { components }\end{array}$} \\
\hline & & & ( $\mu$ mole & $\left.\mathrm{L}^{-1}\right)$ \\
\hline & & Diuron & Diquat & Terbutryn \\
\hline Mixture $\mathrm{B}_{1}$ & $0.70: 0.30: 0$ & 108 & 28 & 0 \\
\hline Mixture $\mathrm{B}_{2}$ & $0.50: 0.50: 0$ & 77 & 47 & 0 \\
\hline Mixture $\mathrm{B}_{3}$ & $0.30: 0.70: 0$ & 43 & 67 & 0 \\
\hline Mixture $\mathrm{T}_{1}$ & $0.333: 0.333: 0.333$ & 51 & 32 & 35 \\
\hline Mixture $\mathrm{T}_{2}$ & $0.50: 0.25: 0.25$ & 77 & 24 & 26 \\
\hline Mixture $\mathrm{T}_{3}$ & $0.25: 0.50: 0.25$ & 39 & 48 & 26 \\
\hline Mixture $\mathrm{T}_{4}$ & $0.25: 0.25: 0.50$ & 39 & 24 & 52 \\
\hline Mixture $\mathrm{T}_{5}$ & $0.15: 0.15: 0.70$ & 23 & 14 & 73 \\
\hline Mixture $\mathrm{T}_{6}$ & $0.70: 0.15: 0.15$ & 108 & 14 & 16 \\
\hline
\end{tabular}

Where B T, and v represent binary tertiary and volume

\section{Determination of synergism or antagonism of mixtures}

The mixture toxicity index (MTI) was estimated according to previous methods (Konemann 1981) to indicate synergetic and/or antagonistic effects of herbicides mixtures. MTI $=1$ $(\log \mathrm{M} / \log \mathrm{n})$, where $\mathrm{M}=\sum \mathrm{c} / \mathrm{EC}_{50}$ at $50 \%$ effect in the mixture and $\mathrm{n}=$ total number of compounds in the mixture. According to the MTI value, the mixture toxicity can be subdivided into 4 groups: antagonism effect $(\mathrm{MTI}<0)$, no addition effect $(\mathrm{MTI}=0)$, partial addition effect $(0<\mathrm{MTI}<$ 1) and concentration addition effect (MTI $\geq 1)$.

\section{Chemical assay technique}

Cyanobacterial mats can reduce thiazolyl blue tetrazolium bromide and change the solution color from yellow to dark blue (purple formazan). In this procedure, a stock solution of $1.2 \mathrm{~g} \mathrm{~L}^{-1}$ thiazolyl blue was used in the chemical assay to obtain a yellow color and $2 \mathrm{~mL}$ of this stock solution were added to each control and treated flasks.

The change in yellow color in the control and treated samples was measured by determining the optical densities at wavelength $570 \mathrm{~nm}$ (at time zero samples) and a reference wavelength of $630 \mathrm{~nm}$ (after the change of color occurred) as previously described (Zilberg, \& Sinai, 2006). The OD of the samples was measured at time $0,24,48,72$, and $96 \mathrm{hr}$. Toxicity of a compound at a certain concentration was evaluated by plotting $\%\left(\mathrm{OD}_{\mathrm{c}}-\mathrm{OD}_{\mathrm{t}}\right) / \mathrm{OD}$ versus the concentration, which generated a linear relationship. The dynamics of cyanobacterial mats growth in the control samples were evaluated by plotting time versus the $\mathrm{OD}_{\max }$ 
$/ \mathrm{OD}_{0} \cdot \mathrm{EC}_{50}$ and $\mathrm{ET}_{50}$ were estimated in the same way as described in the bioassay test Eq (1).

\section{Statistical analysis}

All experiments were performed in five replicates. Averages and standard deviations of the growth inhibition were calculated and fitted to the regression analysis. The averages of growth inhibition were compared by Tukeys test and P-values were determined to evaluate the differences among treatments. One-way ANOVA test was followed using an Excel program.

\section{RESULTS}

The tested compounds, Diuron Diquat and Terbutryn, (Fig. 1) are herbicides widely used in the region for weed control (Tomiln, 2000). They have different physic-chemical properties (Table 1).

Cyanobacterial mats were collected from a nature protected area (Wadi Gaza), which contained a variety of biodiversity (Abed et al., 2002). The growth media of cyanobacterial mats had the following properties: total dissolved salts (TDS) were $3337.5 \pm 238.67 ; \mathrm{pH}$ value $8.53 \pm 0.38$.

\section{Growth of cyanobacterial mats under laboratory conditions}

Growth phases of cyanobacterial mats after $192 \mathrm{~h}$ of incubation under laboratory conditions are shown in Figure $2 \mathrm{a}$, and the relative growth is shown in Fig $2 \mathrm{~b}$. The data in Figure 2a clearly shows 4 phases of cyanobacterial mat growth, whereas the relative growth (Fig 2b) shows overlaps of the standard deviation in almost all cases of growth monitoring. This indicates no significant differences in growth during the entire experimental period and suggests homogeneity of bacterial growth during the experimental period regardless of changes in temperature. Interestingly, the log phase started after $24 \mathrm{~h}$ and ended about $100 \mathrm{~h}$. Accordingly, all toxicity measurements were determined during this period.

\section{TOXICITY TESTS}

\section{Single toxic tests}

The effect of Diuron, Diquat and Terbutryn concentrations and exposure time on cyanobacterial mats growth are shown in figure 3 . It can be seen that $\%$ growth inhibition increased rapidly in all cases as the tested concentration increased up to $2 \mu \mathrm{mol} / \mathrm{L}-1$. A further increase on the tested concentrations did not show a similar increase in the \% growth inhibition. In addition, $\%$ growth inhibition of a tested concentration increased as exposure time increased (Fig. 3, left panel). The data in figure 3 were converted to the corresponding log scale and used to estimate toxicity parameters $\left(\mathrm{EC}_{50}, \mathrm{LT}_{50}, \mathrm{r}^{2}\right.$ values and regression equations). The toxicity parameters of a single test are presented in Table 3.

Table 3. Toxicity parameters of individual tests.

\begin{tabular}{lcccccc}
\hline & \multicolumn{2}{c}{ Effect of concentration } & \multicolumn{3}{c}{ Effect of concentration } \\
\cline { 2 - 7 } Compound & $\begin{array}{c}\mathrm{EC}_{50} \\
(\mu \text { mole } \\
\left.\mathrm{L}^{-1}\right)\end{array}$ & $\boldsymbol{r}^{2}$ & Equation & $\mathrm{ET}_{50}(\mathrm{~h})$ & $r^{2}$ & Equation \\
\hline Diuron & 0.009 & 0.90 & $\begin{array}{c}\mathrm{Y}=11.65 \mathrm{X}+ \\
73.7\end{array}$ & 32.32 & $0.99 \mathrm{Y}=82.96 \mathrm{X}-75.23$ \\
Diquat & 0.034 & 0.97 & $\begin{array}{c}\mathrm{Y}=7.88 \mathrm{X}+ \\
61.57\end{array}$ & 35.89 & $0.92 \mathrm{Y}=56.08 \mathrm{X}-37.20$ \\
& & & & & & \\
Terbutryn & 0.381 & 0.96 & $\begin{array}{c}\mathrm{Y}=23.09 \mathrm{X}+ \\
59.65\end{array}$ & 23.45 & $0.99 \mathrm{Y}=47.43 \mathrm{X}-34.99$ \\
\end{tabular}

Where $\mathrm{EC}_{50}, \mathrm{r} 2$, and $\mathrm{ET}_{50}$ are effective concentration, regression coefficient and effective time, respectively
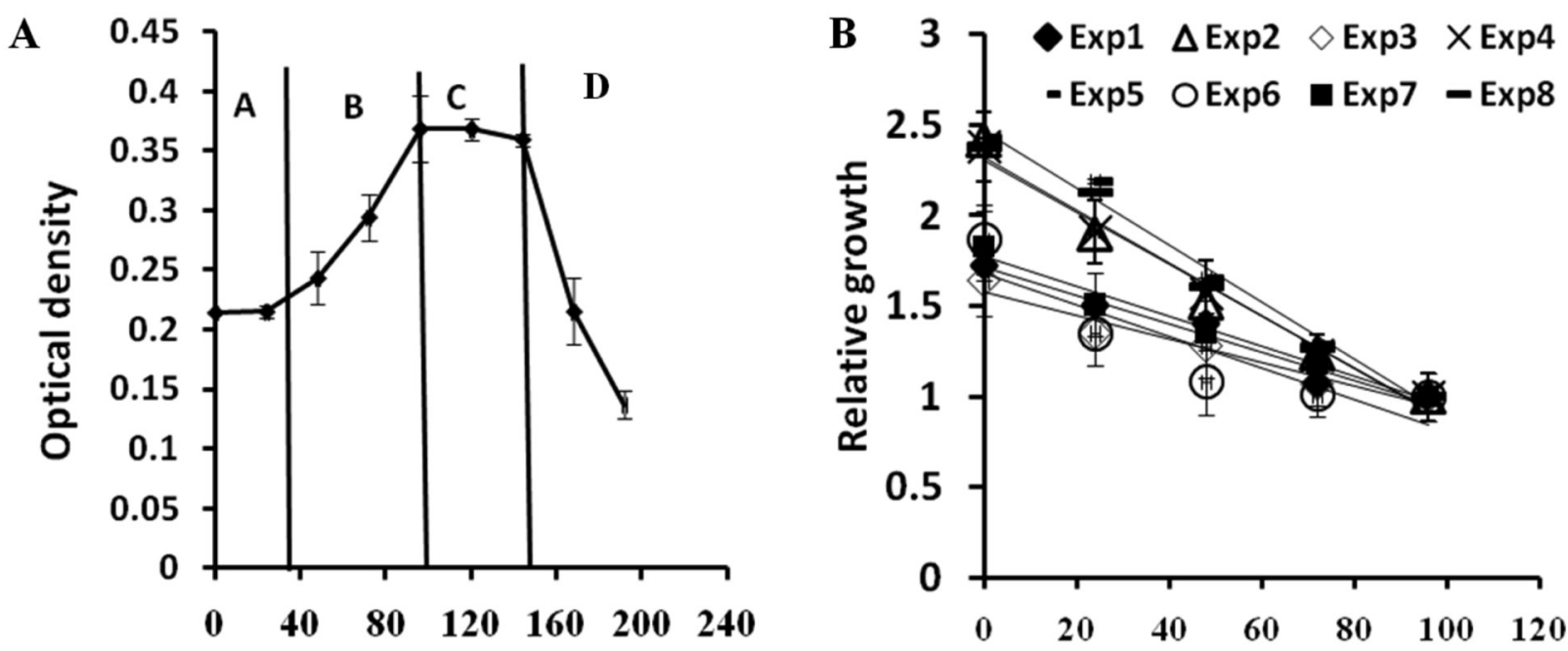

Figure 2. Population growth dynamics of cyanobacterial mats cells (panel A) and relative growth of cyanobacteria (panel B). 


\section{Toxicity of binary and tertiary mixtures}

Toxicities (\% GI) of binary mixtures B1-B3 on cyanobacterial mats cells are shown in figure 4. It is clear that $\%$ growth inhibition reached $70 \%$ at concentrations below $0.2 \mathrm{TU}$ in the case of B1, whereas for B2 and B3 it did not exceed $60 \%$ at the same concentration. A further increase of the tested concentrations of the three mixtures did not show a significant increase in \% growth inhibition. Effect of time on the toxicity of the mixture (Fig. 4, right panel) clearly shows increased toxicity as exposure time increased. Converting the data in Figure 4 to the corresponding log scale enabled the calculation of toxicity parameters $\left(\mathrm{EC}_{50}, \mathrm{ET}_{50}\right.$ and $\mathrm{r} 2$ values). The data are presented in Table 3.

Toxicity of tertiary mixtures $\left(\mathrm{T}_{1}-\mathrm{T}_{6}\right)$ on the growth of cyanobacterial mats cells are shown in figure 5. Similar to Figure 4, there are tremendous increases of \% growth inhibition as the concentration of tertiary mixture increased up to $0.2 \mathrm{TU}$. Then a further increase in the tested concentration did not show a significant increase of \% growth inhibition, except for the case of T1. As previously shown (Fig. 3 and 4), $\%$ growth inhibition increased as the exposure time increased. Influence of exposure time of the toxicity of mixtures is shown in Figure 6. Toxicity parameters of binary and tertiary mixtures are shown in Table 4.

Statistical analyses detected significant differences in the following tests: Diuron + Diquat, $\mathrm{p}$-value $=0.03$; Mixture $\mathrm{T}_{1}+$ Diuron, $\mathrm{p}$-value $=0.02$; Mixture $\mathrm{B}_{2}+$ Mixture $\mathrm{T}_{7}, \mathrm{p}$-value $=0.02$; Mixture $\mathrm{T}_{7}+$ Mixture $\mathrm{T}_{4} \mathrm{p}$-value $=0.002 ;$ Mixture $\mathrm{T}_{2}+$ Mixture $\mathrm{T}_{4}, \mathrm{p}$-value $=0.003$; and Mixture $\mathrm{T}_{1}+$ Mixture $\mathrm{T}_{3}$, $\mathrm{p}$-value $=6.15 \mathrm{E}-06$.

\section{Chemical assay technique}

\section{Toxic effect as a function of herbicide concentrations}

Toxicity of Diuron concentrations on the ability of cyanobacterial mat to reduce Thiazol blue is shown in figure 7. It can be seen that a gradual decrease in color reduction was observed as the tested concentration of Diuron increased. The data in figure 7 were converted to the corresponding log scale to determine the toxicity parameters and are presented here: $\mathrm{EC}_{50}$ was $178.4 \mu$ mole $\mathrm{L}^{-1}$ and the corresponding $\mathrm{R}^{2}$ value was 0.84 . In contrast, $\mathrm{ET}_{50}$ was $113.92 \mathrm{~h}$ and the corresponding $\mathrm{r} 2$ value was 0.98 .

\section{DISCUSSION}

The data presented in Table 1 clearly indicates that the tested compounds have different molecular weights, $\mathrm{H}$ constant, a $\log \mathrm{K}_{\text {ow }}$ value, and belong to different chemical groups that have different mode of actions. These changes in the physic-ochemical properties of the compounds may have a critical rule in the toxicity of their mixture. Moreover, the chemical structures of these compounds (Fig. 1) clearly shows that the each molecule has a different functional group, which may enable hydrophobic interaction in the mixture and the formation of larger molecules that may have different toxicities. The suggestion of hydrophobic interaction was previously suggested for other Cases (El-Nahhal \& Safi 2004).

The data presented in Figure (2a) indicated four growth phases of cyanobacterial mats cells. These results agree with the recent study by El-Nahhal \& Alshanti 2015. A noteworthy outcome of the study is that the adaptation phase (Lag phase) took $24 \mathrm{~h}$ followed by rapid growth (log phase) up to $96 \mathrm{~h}$, then a stationary phase up to $150 \mathrm{~h}$ was followed by a sharp decay up to $200 \mathrm{~h}$. Furthermore, the optical density of cyanobacterial mat growth after $200 \mathrm{~h}$ did not reach 0 because the dead cells contributed to the optical density of the suspension. This indicates that the life cycle is too short and the bacteria can restart the growth phases. The data in Figure $2 b$ clearly indicated linear relationships in all of the experiments and demonstrated the overlap of the standard deviation in most of the points except at time 0 . This reflects on the diversity of the cyanobacterial mats in the samples. These data agree with Abed et al. (2002) who demonstrated the biodiversity of Wadi Gaza. Of special interest is that the log phase of the cyanobacteria increased rapidly up to $100 \mathrm{~h}$. All the toxicity tests were determined in this period.

\section{Toxicity tests}

The toxicity of herbicides (Fig. 3) increased rapidly as the concentration of each compound increased in the solution. As the concentration increased above $5 \mu \mathrm{mole}^{-1}$ of each herbicide in the solution, a steady increase of toxicity was observed in all cases. The explanation is that the majority of cyanobacterial mats are sensitive species; accordingly at low concentrations their growth was inhibited. Raising the concentration did not further increase the toxic effect, suggesting that the remaining population of cyanobacterial mats were tolerant species or resistant to herbicide concentrations. Similar observation were recently reported with fish and mosquitoes (El-Nahhal \& El-Dahdouh 2015)

Moreover, at concentrations above $2.5 \mu$ mole $\mathrm{L}^{-1}$, the herbicides tend to evaporate from the system due to a high evaporation rate at high temperatures, according to Henry's Law Constant (Table 1). Furthermore, due to the salinity of the growth media, herbicide molecules tend to be salted out from the aqueous phase. In this case, the effective concentration of the herbicide is reduced and decreased or a steady-state toxicity was observed.

Nevertheless, the relationships between herbicide concentrations and toxicity (\% growth inhibition) indicated increases of toxicity as exposure time increased. Similar results were shown previously (Delorenzo et al. 2001). In contrast, very low concentrations of tested herbicides stimulated both growth and chlorophyll a content of soil green alga (Ma et al. 2003). The data in Table 4 clearly shows the toxicity parameters of single tests; Diuron is the most toxic herbicide followed by Diquat and Terbutryn as shown by the value of $\mathrm{EC}_{50}$. The lowest value of $\mathrm{EC}_{50}$ indicates the highest toxicity. 

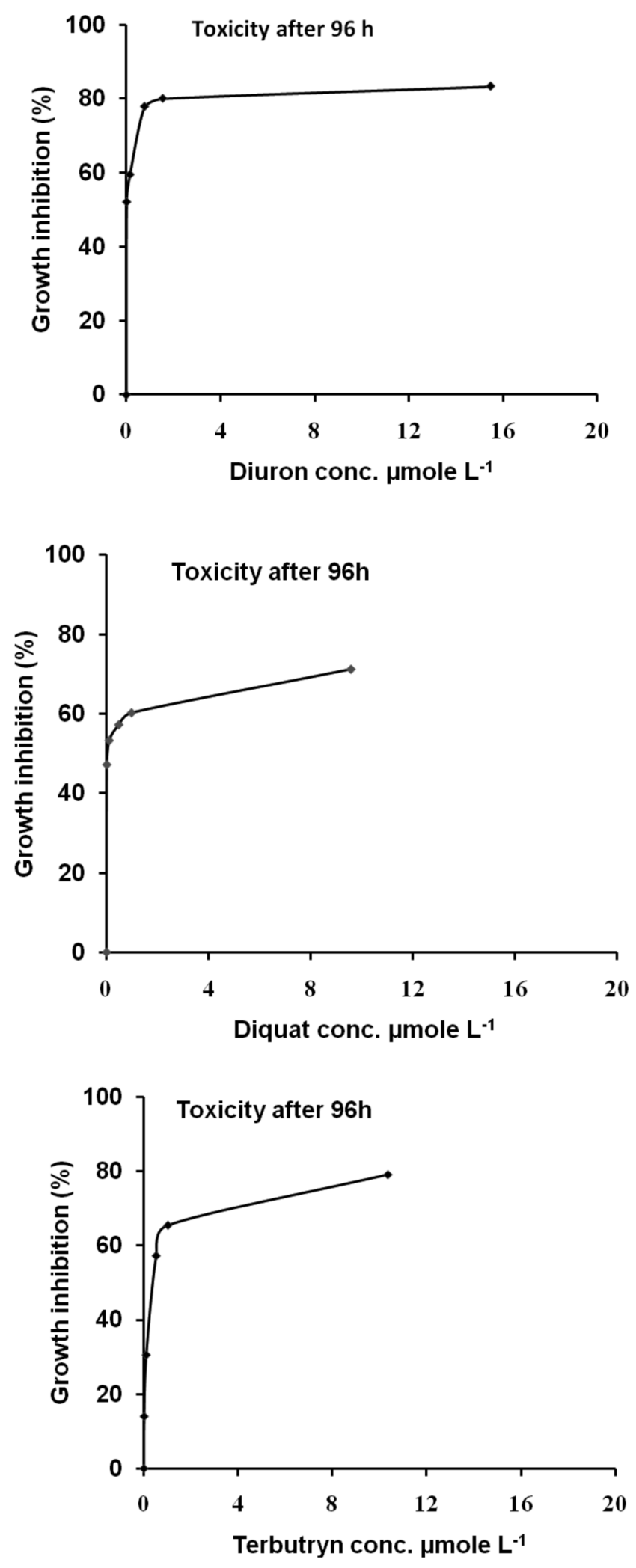
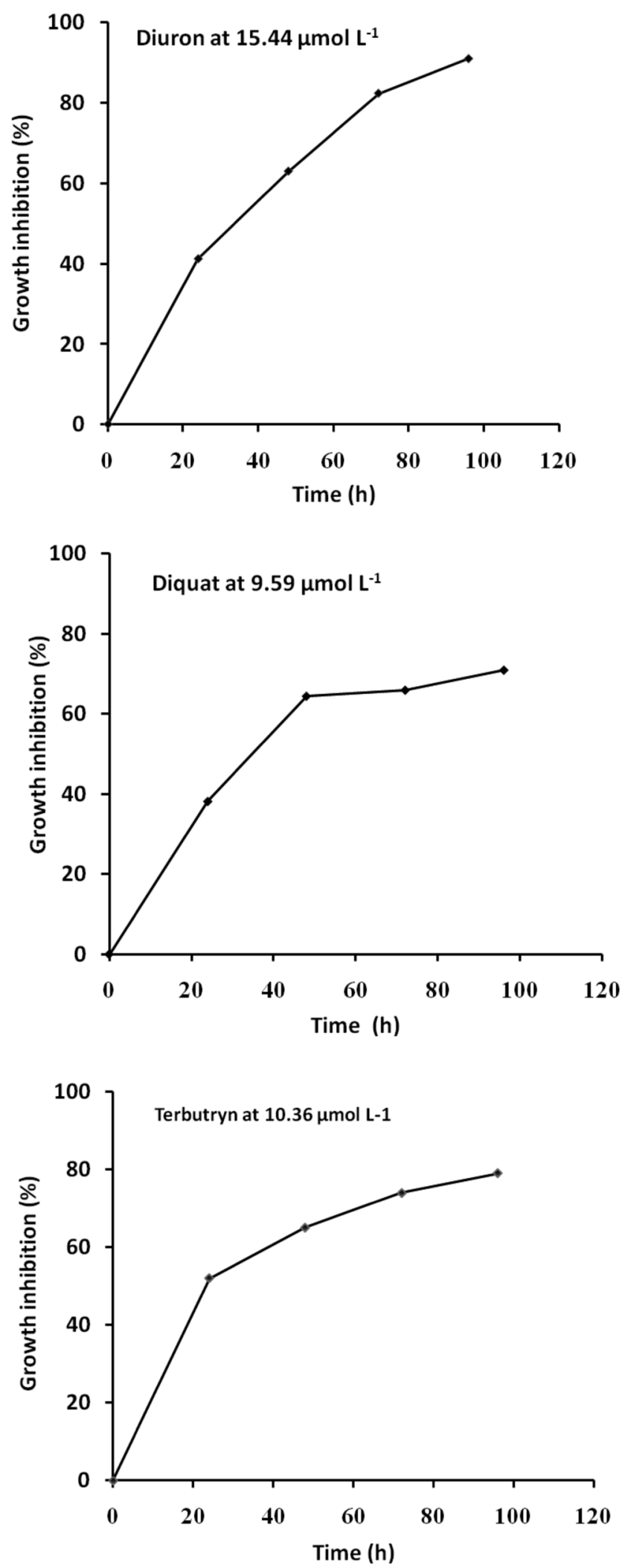

Figure 3. Percent growth inhibition of cyanobacterial mats cells versus concentration and time of Diuron, Diquat and Terbutryn.

By comparing $\mathrm{LT}_{50}$ values, Diuron and Diquat have higher values of $\mathrm{LT}_{50}$ than Terbutryn. These results can be explained by two factors; the first is the $\mathrm{K}_{\mathrm{OW}}$ value of each herbicide (Table 1). Diuron has a $\mathrm{K}_{\mathrm{OW}}$ value lower than Terbutryn due to its possible diffusion from water to cyanobacterial mats cells, which takes a longer time to produce the effect. The second factor is that the mode of action of Terbutryn is different from the others. Similar observations were shown previously for other studies (Singh \& Datta, 2005; Chen et al. 2007). However, the tested herbicides may inhibit photosystem I and/or II and thus the population growth was reduced. Our results are in agreement with Min et al. (2001) who 

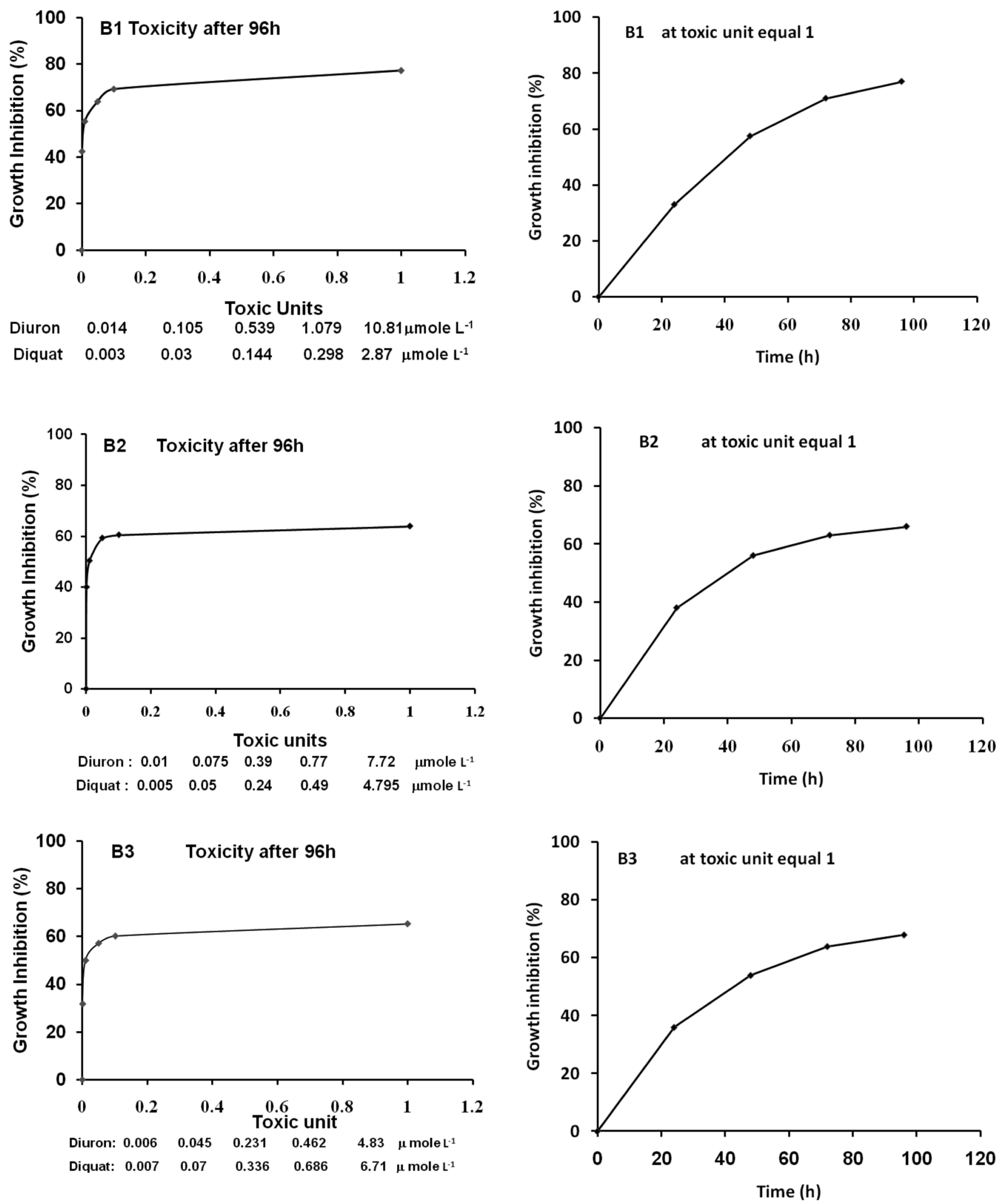

Figure 4. Effect of Diuron Diquat mixtures B1, B2 and B3 at 0.70: 0.30: 50:50 and 30:70 mixing portions of the stock solutions on the growth of cyanobacterial mats cells after $96 \mathrm{~h}$.

found that butachlor can significantly suppress the growth, photosynthesis and respiration of Ceratophyllum demersum. However, the presented results clearly showed low growth inhibition at low applied concentrations. The growth inhibition tended to increase as the applied concentration increased in the solution. Moreover, at a slightly higher concentration $(2 \mu$ mole $\mathrm{L}^{-1}$ ), no further increase in growth inhibition was observed. The explanation is that at low applied concentrations, 

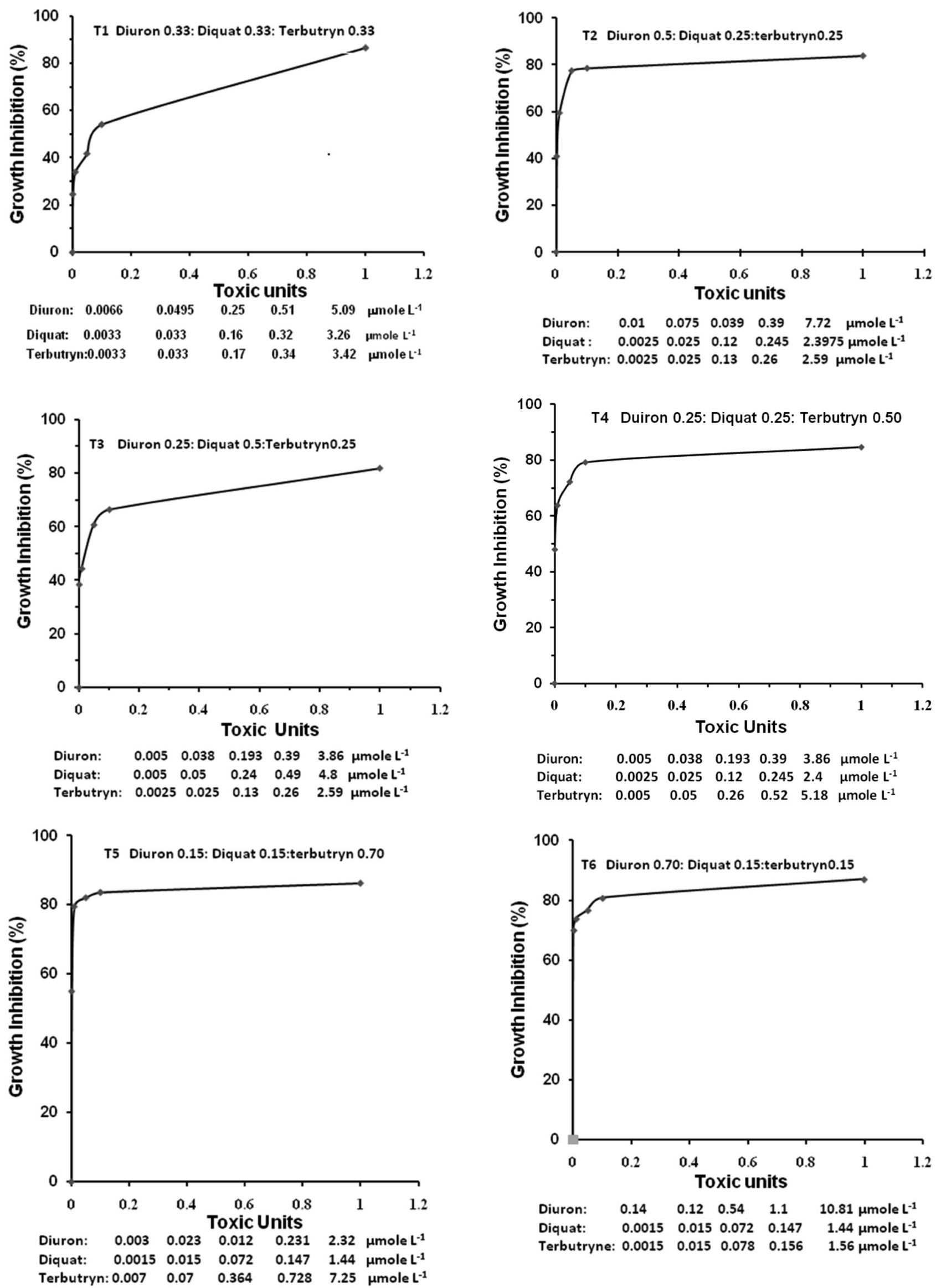

Figure 5. Effect of Diuron Diquat and Terbutryn mixtures at T1, (0.33:0.33:0.33); T2 (0.50: 0.25: 0.25); T3 (0.25: $0.50: 0.25), \mathrm{T} 4(0.25: 0.25: 0.50)$; T5 $(0.15: 0.15: 0.70)$; and T6 $(0.70: 0.15: 0.15)$ on the growth of cyanobacterial mats cells after $96 \mathrm{~h}$. 

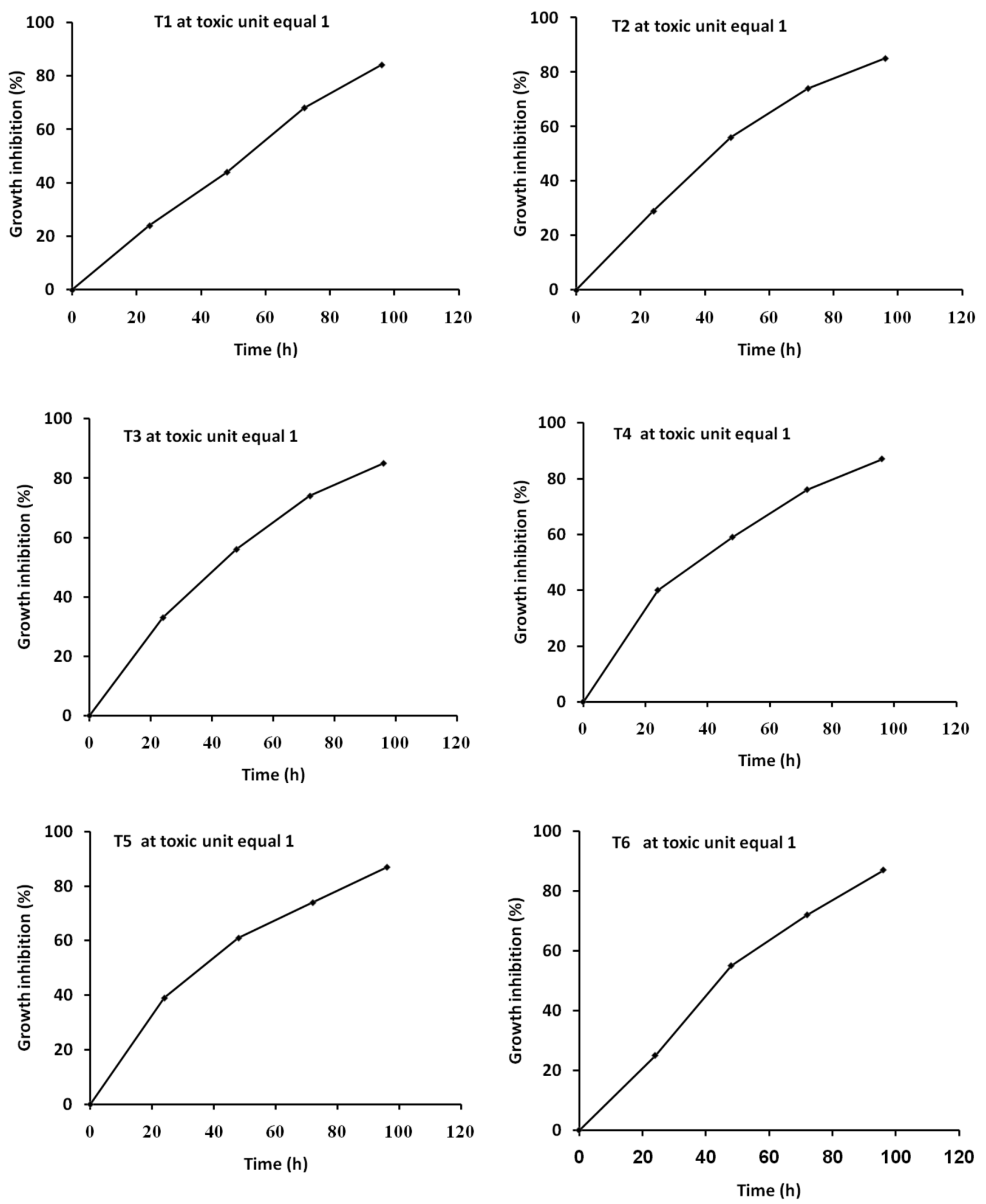

Figure 6. Effect of exposure time of mixtures T1-T6 on the growth of cyanobacterial mats cells.

cyanobacterial mats may undergo fast adaptation and use the herbicide as a source of energy as shown in other studies (El-Nahhal el al., 2013), or undergo community changes (Abed et al., 2002). A steady state growth inhibition was observed at concentrations above $\left(2 \mu\right.$ mole $\left.\mathrm{L}^{-1}\right)$. Furthermore, cyanobacterial mat may contain sensitive, tolerant and resistant species to toxic substances, thus at low applied concentrations the sensitive species died and the tolerant and resistant species 
remained in the solution. Both types did not have a linear response with herbicide concentrations. This agrees with Liu et al. (2012) who isolated antibiotic resistant bacteria from an agricultural area treated with cattle manure. In addition, the dead cyanobacterial mats cells remain in growth media and are counted as alive cells when the optical density is measured as an indicator of bacterial growth.

The comparison of toxicity parameters indicates that Duiron was the most toxic among the individual tests due to its lowest $\mathrm{EC}_{50}$ (Table 3). The explanation is that as the concentration increased, the needed fraction of herbicides to inhibit the growth of cyanobacterial mats increased and, consequently, the $\%$ growth inhibition increased. On the other hand, as exposure time increased, the growth inhibition increased. The explanation of these results is that the herbicide needs time to be partitioned from water (the aquatic medium of testing) to organic layers of bacterial cells (cyanobacterial cell wall and cell membrane) according to its $\mathrm{K}_{\mathrm{Ow}}$ which is equal to 2.85 (Table 1 ).

None of the tested compounds reached $100 \%$ growth inhibition at $96 \mathrm{~h}$. An explanation may be because each compound had a different value of Henry's law constant (Table 1), which correlated with the evaporation of the tested herbicide. As the experiments were performed in open flasks, a fraction of the herbicide concentration may have evaporated from the flasks. Accordingly, $100 \%$ growth inhibition was not reached. El-Nahhal \& Ashanti (2015) found similar results.

Toxicity of binary and tertiary mixtures (Fig. 4-5) have a nearly similar trend of effects. It can be seen that $\%$ growth inhibition of cyanobacterial mats increased as the concentrations of the herbicide increased in the solution. At toxic units (TU) below 0.2 , the $\%$ growth inhibition reached approximately $70 \%$, whereas a little increase in the $\%$ growth inhibition was observed above $0.2 \mathrm{TU}_{\mathrm{s}}$. This observation was most dominant in all binary and tertiary mixtures. Effect of toxicity versus exposure time is nearly similar in single and binary toxicity tests. An explanation of these results is associated with the values of $\log \mathrm{K}_{\mathrm{ow}}$ and $\mathrm{H}$-constant. More elaboration is given above.

Comparison of toxicity parameters of binary and tertiary mixtures is shown in Table 4. It can be seen that the $\mathrm{EC}_{50}$ value of binary mixtures B1 is the lowest among binary mixtures. This indicates that mixture B1 was the most toxic among all binary mixtures. This mixture (B1) contained 0.7 Diuron, whereas B2 and B3 contained 0.5 and 0.3 Diuron, respectively. This indicates that the Diuron fraction in the binary mixtures is important to the increase of toxicity of the mixture. Nevertheless, the $\mathrm{EC}_{50}$ value of $\mathrm{B} 1$ was 0.004 $\mathrm{TU}_{\mathrm{S}}$ which is several times lower than the others and thus indicating high toxicity. This agrees with (Chen et al. 2007) who found that diuron is very toxic to cyanobacteria in different mixtures. The regression factor $\left(\mathrm{R}^{2}\right)$ associated with $\mathrm{EC}_{50}$ of binary mixture ranged between 0.92-0.98, indicating a strong positive association. Moreover, $\mathrm{LT}_{50}$ values of the binary mixtures are very close to each other but the mixture $\mathrm{B} 1$ has the lowest $\mathrm{LT}_{50} 40,23 \mathrm{~h}$ and the values tend to increase as the fraction of Diuron decreased in the mixture. This is due to the $\log \mathrm{K}_{\text {ow }}$ value of Diuron, which is a key factor because Diquat has a negative value (Table 1) due to its high solubility.

Table 4 highlights that toxicity of the tertiary mixture increased as the fraction of Terbutryn increased to 0.7. However, it is obvious that the tertiary mixture T5 had the lowest $\mathrm{EC}_{50}$ value (1.5E-11 TUs), followed by $\mathrm{T} 7$ and $\mathrm{T} 6$. This indicates that mixture $\mathrm{T} 5$ is the most toxic among all of the tertiary mixtures. Mixture (T5) contained 0.15 Diuron, 0.15 Diquat and 0.7 Terbutryn. This indicates that Terbutryn is important in increasing the toxicity of the mixture. However, reducing the fraction of Terbutryn to 0.5 or 0.25 in the mixture resulted in a decrease in toxicity of the mixture as shown by the reduction of $\mathrm{EC}_{50}$. Moreover, increasing the Diuron fraction in the tertiary mixtures resulted in increasing the toxicity. Accordingly, Diuron and Terbutryn are responsible for increasing the toxicity of the mixture. The explanation of these results is related to the $\log \mathrm{K}_{\text {ow }}$ values, which are very high compared to that of Diquat and $\mathrm{H}$ constants (Table 1). A similar explanation was previously given in other studies (Ma et al. 2010). $\mathrm{ET}_{50}$ values of the

Table 4 . Toxicity parameters of binary and tertiary mixtures.

\begin{tabular}{|c|c|c|c|c|c|c|}
\hline \multirow[b]{2}{*}{ Mixture } & \multirow[b]{2}{*}{ Fractions } & \multicolumn{2}{|c|}{$\begin{array}{c}\text { Effect of } \\
\text { concentration }\end{array}$} & \multicolumn{2}{|c|}{$\begin{array}{c}\text { Effect of } \\
\text { concentration }\end{array}$} & \multirow[t]{2}{*}{ MTI } \\
\hline & & $\begin{array}{l}\mathbf{E C}_{50} \\
\text { (TUs) }\end{array}$ & $\mathbf{r}^{2}$ & $\mathbf{E T}_{50}(\mathrm{~h})$ & $r^{2}$ & \\
\hline B1 & $\begin{array}{c}\text { Diuron } 0.70 \text { :Diquat } \\
0.30\end{array}$ & 0.004 & 0.98 & 40.23 & 0.99 & -1.12 \\
\hline B2 & $\begin{array}{c}\text { Diuron } 0.50 \text { :Diquat } \\
0.50\end{array}$ & 0.01 & 0.92 & 41.64 & 0.98 & 0.37 \\
\hline B3 & $\begin{array}{l}\text { Diuron 0.3:Diquat } \\
0.70\end{array}$ & 0.012 & 0.92 & 46.10 & 0.99 & 1.61 \\
\hline $\mathrm{T} 1$ & $\begin{array}{c}\text { Diuron } 0.33: \text { Diquat } \\
0.33: \\
\text { Terbutryn } 0.33\end{array}$ & 0.043 & 0.90 & 44.17 & 0.99 & 2.07 \\
\hline $\mathrm{T} 2$ & $\begin{array}{l}\text { Diuron } 0.50: \text { Diquat } \\
0.25: \text { Terbutryn } 0.25\end{array}$ & 0.002 & 0.90 & 47.52 & 0.98 & -0.71 \\
\hline $\mathrm{T} 3$ & $\begin{array}{l}\text { Diuron } 0.25 \text { : Diquat } \\
0.50: \text { Terbutryn } 0.25\end{array}$ & 0.01 & 0.96 & 41.11 & 0.99 & 0.82 \\
\hline $\mathrm{T} 4$ & $\begin{array}{l}\text { Diuron } 0.25: \text { Diquat } \\
0.25: \text { Terbutryn } 0.50\end{array}$ & 0.001 & 0.96 & 38.94 & 0.99 & -1.3 \\
\hline T5 & $\begin{array}{l}\text { Diuron } 0.15 \text { : Diquat } \\
0.15: \text { Terbutryn } 0.70\end{array}$ & $1.5 \mathrm{E}-11$ & 0.99 & 34.32 & 0.99 & -7.5 \\
\hline T6 & $\begin{array}{l}\text { Diuron } 0.70: \text { Diquat } \\
0.15: \text { Terbutryn } 0.15\end{array}$ & $7.06 \mathrm{E}-07$ & 0.97 & 43.23 & 0.99 & -4 \\
\hline
\end{tabular}

Where TUand MTI are toxic unit, and mixture toxicity index respectively. 
tertiary mixtures ranged between 34.32 - 47.52h. The differences of $\mathrm{ET}_{50}$ values may be attributed to the ability of cyanobacterial mats to degrade the tested herbicides for use as an energy source. This statement agrees with El-Nahhal et al. (2013) and Safi et al. (2014) who showed the ability of cyanobacterial mats to degrade acetochlor and Diuron in soil and aquatic systems.

A comparison of tertiary mixtures indicated that the mixture $\mathrm{T}_{5}$ is the most toxic one and has an $\mathrm{EC}_{50}$ value, which equals $1.5 \mathrm{E}-11$. Furthermore $\mathrm{T}_{6}$ and $\mathrm{T} 4$ have very low $\mathrm{EC}_{50}$ values, indicating high toxicity. Nevertheless, the toxicity order of mixtures can be ranked as T5 $>\mathrm{T} 6>\mathrm{T} 4>\mathrm{T} 2>\mathrm{T} 3>$ T1. These results classify the mixtures into two groups: group 1 includes mixtures that have concentration portions equal to or below 0.5. This class includes the mixtures $\mathrm{T}_{1}, \mathrm{~T}_{2}, \mathrm{~T}_{3}$ and $\mathrm{T}_{4}$. Group 2 includes mixtures that have concentration portions equal to 0.7. This class includes the mixtures $T_{5}$ and $T_{6}$. In group 1, it appears that Diuron and Terbutryn are the key toxic compounds of the mixture, where each has a concentration portion equal to 0.5 . In this group, $\mathrm{EC}_{50}$ values are several times lower than mixtures having equal concentration portions as in $\mathrm{T}_{1}$ or lower than a 0.5 portion as in mixture $\mathrm{T}_{3}$.

In group two, $\mathrm{T} 5$ is the most toxic. This result suggests that the Terbutryn portion is the key toxic compound among others. This result agrees with Ma et al. (2010) who found that the toxic effect of the mixture increased as its concentration increased.

Using a mixture toxicity index (MTI) (Konenmann 1981) enabled the classification of the mixture effects (Table 4) into three categories: Category 1: partial addition, which included the MTI values that are more than zero and below $1\left(\mathrm{~B}_{2}+\right.$ $\mathrm{T}_{3}$ ). Category 2: supra addition $\mathrm{B}_{3}+\mathrm{T}_{1}(>1)$, and category 3 : antagonism $\mathrm{B}_{1}+\mathrm{T}_{2}+\mathrm{T}_{4}+\mathrm{T}_{5}$ and $\mathrm{T}_{6}(<0)$.

The toxicity of Diuron on cyanobacterial mats using Thiazol blue as an indicator is shown in figure 7. The exposure of cyanobacterial mats solutions to a gradient of concentrations of Diuron over $96 \mathrm{~h}$ did not lead to clear toxic effects. Similar studies showed positive results when

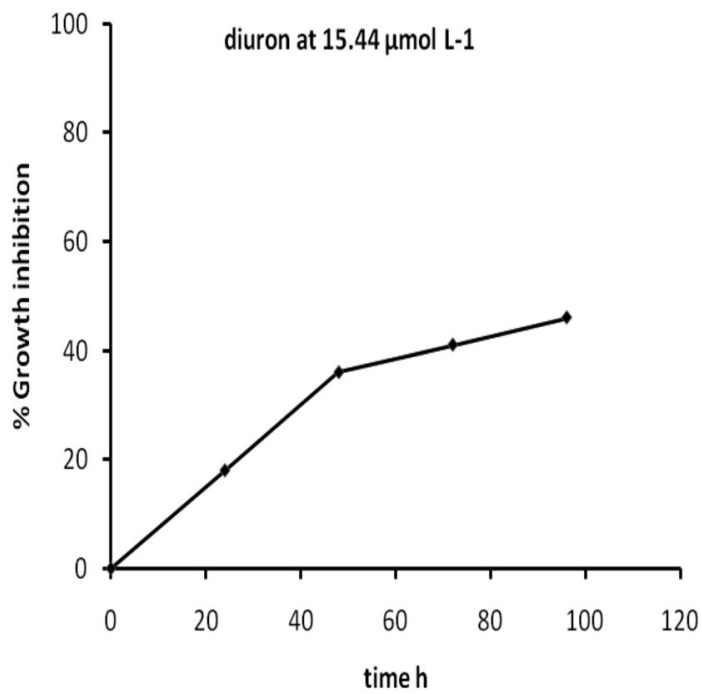

the protozoa Tetrahymena $s p$. were used as test organisms (Zilberg \& Sinai,2006). In our study, the results of \% growth inhibition by using Thiazolyl blue were not systematic and there were no significant differences observed. This might be because An explanation the tested organism in our study was prokaryotic while in the case of Zilberg \& Sinai, (2006) it was eukaryatic. Cyanobacterial mats cells as prokaryotic organisms may not have the capability to reduce or break the Thiazol blue as in the case of protozoa.

\section{CONCLUSION}

This study showed fast growth and adaptation of cyanobacterial mats under laboratory conditions. Single toxicity tests clearly demonstrated that Diuron is more toxic than Diquat and Terbutryn. Furthermore, the results of mixture toxicity indicated that the highest toxicity of mixtures contained a high fraction of Diuron or Terbutryn. In addition, $\mathrm{K}_{\mathrm{OW}}$ and Henry law constants of each herbicide strongly influenced the toxicity of all tests.

The $\mathrm{EC}_{50}$ values, in $\mu$ mole $\mathrm{L}^{-1}$, of the single test were: Diuron $(0.009)<$ Diquat $(0.034)<$ Terburtyn $(0.38)$ and $\mathrm{ET}_{50}$ values were Diquat $(35.89 \mathrm{~h})>$ Diuron $(32.32 \mathrm{~h})>$ Terbutryn (23.45 h).

$\mathrm{EC}_{50}$ values of the binary mixtures expressed in $\mathrm{TU}_{\mathrm{S}}$ were the following: $\mathrm{B}_{3}(0.012)>\mathrm{B}_{2}(0.01)>\mathrm{B}_{1}(0.004)$ and $\mathrm{ET}_{50}$ values were: $B_{3}(46.1 \mathrm{~h})>\mathrm{B}_{2}(41.6 \mathrm{~h})>\mathrm{B}_{1}(40.23 \mathrm{~h}) . \mathrm{EC}_{50}$ values of the tertiary mixtures were: $\mathrm{T}_{1}(0.043)>\mathrm{T}_{3}(0.01)$ $>\mathrm{T}_{2}(0.002)>\mathrm{T}_{4}(0.001)>\mathrm{T}_{6}(7.06 \mathrm{E}-07)>\mathrm{T}_{7}(2.9 \mathrm{E}-07)>$ $\mathrm{T}_{5}(1.5 \mathrm{E}-11) . \mathrm{ET}_{50}$ values were: $\mathrm{T}_{2}(47.52)>\mathrm{T}_{1}(44.17)>\mathrm{T}_{6}$ $(43.23)>\mathrm{T}_{3}(41.11)>\mathrm{T}_{4}(38.94)>\mathrm{T}_{5}(34.32)$.

MTI calculations showed a partial addition effect for B2 $(0.37)+\mathrm{T}_{3}(0.82)$, supra addition for $\mathrm{B}_{3}(1.61)+\mathrm{T}_{1}(2.07)$ and antagonism for $\mathrm{B}_{1}(-1.12), \mathrm{T}_{2}(-0.71), \mathrm{T}_{4}(-1.3), \mathrm{T}_{5}(-7.5)$, and $\mathrm{T}_{6}(-4)$.

Cyanobacterial mats were able to reduce the Thiazol blue color to yellow.

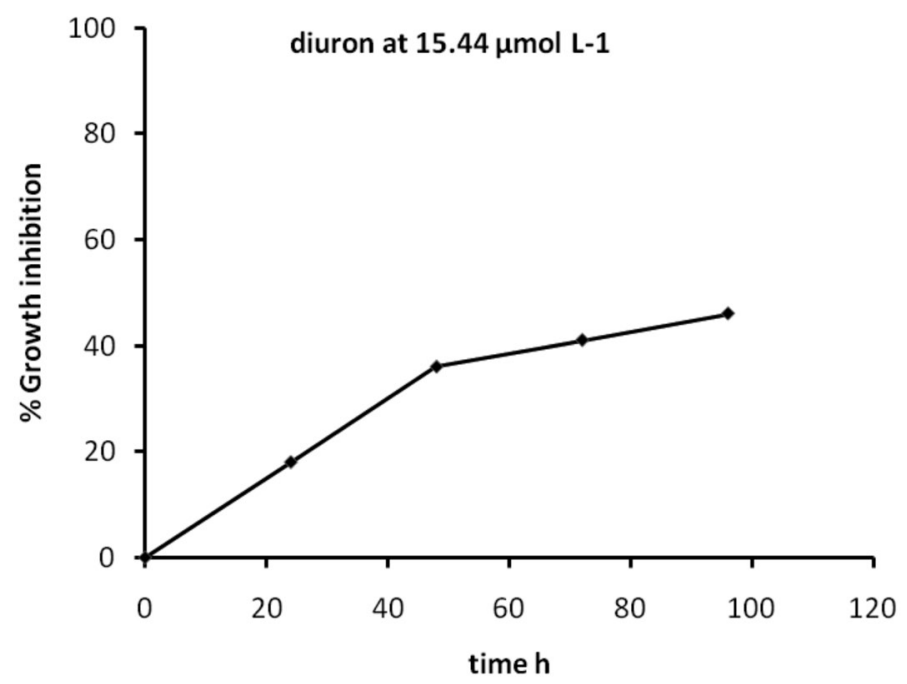

Figure 7. Percent growth inhibition of cyanobacterial mats cells versus concentration of Diuron treated with Thiazol blue after $96 \mathrm{~h}$. 


\section{ACKNOWLEDGMENTS}

Dr Y. El-Nahhal acknowledges the Alexander von Humboldt Stiftung Foundation Fellowship Grant no IVPAL/1104842 STP, Germany. Special thanks go to Prof. Dr. G..Lagaly of Kiel University and to Prof G. Shourrmman, of Liepzc University, Germany.

\section{REFERENCES}

ABED M.A., SAFI M. N., KÖSTER J., D BEER., El-NAHHAL Y., RULLKÖTTER J. \& GARCIA-PICHEL F. 2002. Microbial Diversity of a Heavily Polluted Microbial Mat and Its Community Changes Following Degradation of Petroleum Compounds. Appl. Environ. Microbiol. 68: 1674-1683. http://dx.doi.org/ 10.1128/AEM.68.4.1674-1683.2002.

ASLIM B. \& OZTURKE S. 2009. Toxicity of herbicides to cyanobacterial isolates. J.Environ.Biol. 30: 381-384.

BONNET J., BONNEMOY F., DUSSER M. \& BOHATIER J. 2007. Assessment of the potential toxicity of herbicides and their degradation products to nontarget cells using two microorganisms, the bacteria Vibrio fischeri and the ciliate Tetrahymena pyriformis. Environ. Toxicol. 22:78-91. http:// dx.doi.org/10.1002/tox.20237.

CHEN Z., JUNEAU P. \& Qiu B. 2007. Effects of three pesticides on the growth, photosynthesis and photoinhibition of the edible cyanobacterium Ge-Xian-Mi (Nostoc). Aquat. Toxicol. 81:256265. http://dx.doi.org/ 10.1016/j.aquatox.2006.12.008.

DELORENZO E. M., SCOTT I. G. \& E. ROSS E. PH. 2001. Toxicity of pestisides to aquatic microorganisms. Environ. Toxicol. Chem. 20: 84-98. http://dx.doi.org/10.1002/etc.5620200108

EL-NAHHAL Y. 2004. Contamination and safety status of plant food in Arab countries. J. Appl. Sci. 4:411-417. http://dx.doi.org/ 10.3923/jas.2004.411.417

El-NAHHAL Y.\& HAMDONA N. 2015. Phytotoxicity of the Alachlor, Bromacil and Diuron as single or mixed herbicides applied to wheat, melon, and molokhia . Springerplus. 2015 Jul 22;4:367. http://dx.doi.org/ 10.1186/s40064-015-1148-7. eCollection 2015.

EL-NAHHAL Y., EL-NAJJAR Sh. \& AFFIFI S. 2015. Impact of Organic Contamination on Some Aquatic Organisms. Toxicol. Int.(in press)

EL-NAHHAL Y.\& RADWAN A. 2013. Human health risks: Impact of pesticide application. J. Environ. Earth Sci.3: 199-209. file://C:/Users/sal/Downloads/6403-8433-1-PB.pdf

EL-NAHHAL Y., AWAD Y. \& SAFI J. 2013. Bioremediation of Acetochlor in Soil and Water Systems by Cyanobacterial Mat. Int.J.Geosci. 4: 880-890. http://dx.doi.org/10.4236/ ijg.2013.45082.

EL-NAHHAL Y. \& ASHANIT A. 2015.Toxicity of single and mixtures of antibiotics to cyanobacteria. J.Environ. Anal. Toxicol 5,:274. http://dx.doi.org/10.4172/2161-0525. 1000274.

INDERJIT-KASUSHIK S. 2010. Effect of herbicides with different mode of action on physiological and cellular traits of Anabaena fertilissima cyanobacteria. Paddy Wat. Environ. 8:277-282. http://dx.doi.org/ 10.1007/s10333-010-0208-4

KONEMANN H. 1981. Fish toxicity tests with mixtures of more than two chemicals: A proposal for a quantitative approach and experimental results. Toxicol. 19:229-238. http://dx.doi. org/10.1016/0300-483X(81)90132-3

LIU Y., GAO B., YUE Q., GUAN Y., WANG Y.\& HUANG L.2012. Influences of two antibiotics contaminants on the production, release and toxicity of microcystins. Ecotoxicol. Environ. Saf.77: 79-87. http://dx.doi.org/ 10.1016/j.ecoenv.2011.10.027.

MA J., LIN F, WANG S. \& XU L. 2003. Toxicity of 21 herbicides to Scenedesmus quadricauda. Bull. Environ. Contamin. Toxicol.71:594-601. http://dx.doi.org/ 10.1007/s00128-0038521-x.

MA J., TONG S., WANG P. \& CHEN J.2010. Toxicity of Seven Herbicides to the Three Cyanobacteria Anabaena flos-aquae, Microcystis flos-aquae and Mirocystis flos-aquae and Mirocystis aeruginosa. Int. J.Environ. Res. 4: 347-352. ISSN: 1735-6865.

Miller G. T. 2009. Living in the Environment. Scott Spolman, 16th edition, USA, P:295.

OKMEN G. \& UGER A. 2011. Influence of bispyribac sodiumonnitrogen activity and growth of cyanobacteria isolated from paddy field. Afr. J.Microbiol. Res. 5: 2760-2764. http:// dx.doi.org/ 10.5897/AJMR11.560 .

SAFI M. J., ABU MOURAD T.A. \& YASSIN M.M. 2005. Hematological biomarkers in farm workers exposed to organophosphorus pesticides in the Gaza Strip. Arch. Environ. Occup. Health 60: 235-241. http://dx.doi.org/10.3200/ AEOH.60.5.235-241

SAFI J., AWAD Y. \& EL-NAHHAL Y.2014. Bioremediation of Diuron in Soil and by Cyanobacterial Mat. Ame. J. Plant Sci. 5:1081-1089. http://dx.doi.org/10.4236/ajps.2014.58120

SAUVANT M. P., PEPIN D. \& PICCINNI E.1999. Cyanobacterial mats sp: A tool for toxicological studies. Chemosphere, 38:16311669. http://dx.doi.org/10.1016/S0045-6535(98)00381-6.

SINGH S. \& DATTA P.2005. Growth and survival potentials of immobilized diazotrophic cyanobacterial isolates exposed to common rice field herbicides. World J.Microbiol. Biotechnol. 21: 441-446. http://dx.doi.org/10.1007/s11274-004-1877-1

SPRAGUE B. J. \& RAMSAY B.1965. Lethal levels of mixed copper-zinc solutions for juvenile salmon. J. Fish. Res. Board Can. 22: 425-432. http://dx.doi.org/10.1139/f65-042.

TOMLIN C 2000. The Pesticide Manual. British Crop Protection Council, UK.

WENDT-RASCH L., VAN DEN BRINK J. P., CRUM H. J.S. $\&$ WOIN P. 2004. The effective of pisticides mixture on aquatic ecosystems differing in trophic status : responses of the macrophite Myriophyllum spicatum and periphytic algal community. Ecotoxicol.Environ.Saf. 57:383-398. http://dx.doi. org/10.1016/j.ecoenv.2003.09.010

MIN H., YE Y.F., CHEN Z.Y.,WU W.X., DU Y.F. 2001. Effects of butachlor on microbial populations and enzyme activities in paddy soil. J. Environ. Sci. Health B. 36:581-595. http://dx.doi. org/10.1081/PFC-100106187

ZILBERG D. \& SINAI T. 2006. Optimization and validation of a colorimetric assay for Tetrahymena sp. Survival. Res.Microbiol. 157: 355-359. http://dx.doi.org/10.1016/j.resmic.2005.09.012. 